\title{
Wilde's Language Style in The Picture of Dorian Gray
}

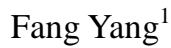 \\ ${ }^{1}$ Department of English Education, School of Foreign Languages, Yancheng Teachers University, Yancheng, Jiangsu, \\ China \\ Correspondence: Yan Cheng, Department of English Education, School of Foreign Languages, Yancheng Teachers \\ University, Yancheng, Jiangsu, China. \\ Received: March 17, 2018 \\ Accepted: April 24, 2018 \\ Online Published: April 29, 2018 \\ doi:10.5430/elr.v7n2p1 \\ URL: https://doi.org/10.5430/elr.v7n2p1
}

\begin{abstract}
Oscar Wilde, a famous Irish Aestheitc Writer, is well-known for the humourous language in his works. As the "lord of language", he deliberately utilizes English as a tool to show the beauty of the language itself. His only novel The Picture of Dorian Gray commendably reveals Wilde's talent in language organizing. This paper outlines Wilde's employing witty rhetorical devices, the harmonious diction, brilliant paradoxes, jocular dialogues and witty epigrams to help readers perceive that succinctness, vividness, impressiveness and meaningfulness form the most important features of the writing style of the novel.
\end{abstract}

Keywords: rhetorical devices, harmonious diction, paradoxes, epigrams, witty dialogues, Aestheic art

\section{Introduction}

"I have one instrument that I know I can command, and that is the English language", said Wilde in an interview published in 1892(Stuart, 1914, p372-373). As a worldwide well-known Irish writer, Oscar Wilde not only declared himself to be "lord of language" (Winwar, 1940, p170), but also made a clever use of the English language as an instrument to add to the vividness, effectiveness and charm of his works.

In The Picture of Dorian Gray, the process of Dorian Gray's degeneration constructs the main thread of the plot and displays Wilde's pondering over art. When Dorian Gray, a wealthy, naive and handsome young man, has his portrait painted, he rashly wishes that he could remain as beautiful, youthful, and alluring as he is in the portrait, though little does he know that his wish will come true. Gradually Gray is stunned to discover that while the face in the painting is aging grotesquely, he is not! In fact, he remains as beautiful as ever. In the novel Wilde blends the magic realistic theme with his witty and humourous language.

It has been over a century since The Picture of Dorian Gray came out in 1891. Although the reassessment of Oscar Wilde since 1950s has brought about many academic researches on Wilde's plays, yet the writing style of the novel has not been much discussed. With no books specially written on the writing style, only several articles discussed similar topics, such as, M. Ellis D'Amico's Wilde's Intellectual Epigrams from the Image-building of Henry Wotton, George Woodcock's The Paradox of Oscar Wilde, etc. Therefore, this thesis will focus on the writing style from analyzing the rhetorical devices, discussing the elegant diction, and appreciating the witty but connotative language of the novel.

\section{Literature Review}

The Aesthetic Movement took place in France in 1830s. The publication of the celebrated preface to Mademoiselle de Maupin (1835), the manifesto of Aestheticism in the French literary world, symbolized the beginning of the French Aesthetic Movement. In 1840s, with kinds of lectures, proseminars and debate meetings to preach Aestheticism, the slogan "art for art's sake" (Liu, 1992) spread quickly throughout the whole France and then to other European countries.

In 1850 the Pre-Raphaelite Brotherhood published The Germ to propagandize the aesthetic belief in Britain, which indicated the beginning of the English Aesthetic Movement. About the spokesmen of Pre-Raphaelite Brotherhood in literature, they were Dante Gabriel Rossetti (1828-1882), his sister Christina Rossetti (1830-1894) and Algernon Charles Swinburne (1837-1909). Different as their writing style was, the attitude towards art and life seemed similar. Walter Pater (1839-1894) proposed that young men should be in search of aesthetic experience and in pursuit of sorts 
of sensual pleasure. He also urged people to seek for sensational pleasure in the artistic creation and to "get as many pulsations as possible into the given time" (Walter, 1986). Oscar Wilde accentuated that real happiness should come from human's untiring pursuit of beauty. In a word, British representatives not only developed and sublimated Gautier's aesthetic viewpoints but also promoted their own opinions that emphasized freedom of human soul. But Wilde's success in England and America was crumbled in 1895 when he was accused of homosexuality and put into prison. From then on, the revulsion against him became more and more intensified, and the Aesthetic Movement itself suffered a severe setback. In the early twentieth century Wilde became despised by the public, and was regarded simply as an outdated socio-cultural phenomenon. However, with the renewed studies on Aestheticism after 1950s, people came to reevaluate Oscar Wilde and acknowledge him as one of the most excellent aesthetic writers not only in Britain but also all over the world.

In Wilde's Age some criticism accused it of having evil effects while others, such as editors in The Christian Leader, favorably compared Oscar Wilde to Edgar Allan Poe, and believed the novel in many aspects a great one. Although there is not a few books specially written on the writing style in The Picture of Dorian Gray in China, yet many literature criticisms have issued articles on it from different angles, such as, WangQiong's The Importance of Being Revealed: The Beauty in Wilde's The Picture of Dorian Gray; Liu Zhaohui's "Différance" of the Theme: A Rereading of The Picture of Dorian Gray; Xu Zheng-fang's A Trial Discussion of the Psychology Symbol of The Picture of Dorian Gray; Zhang Jie-ming's On Wilde's Aestheticism in The Picture of Dorian Gray, etc. Although the above mentioned articles have analyzed the novel by using psychoanalytical, stylistics, and sociological methods, yet few of them have given a systematic or overall review of the writing style of the novel, and opinions still vary as to its artistic importance. Therefore, this thesis will focus on the writing style in the novel by analysing the wit of the rhetorical devices, the harmony of Wilde's diction and the beauty of Wilde's language.

\section{The Wit of Rhetorical Devices}

The Picture of Dorian Gray has never lost its appeal to the readers for a century. This is not only because of its absorbing plots, animated characters and intense conflicts, but also because of the witty rhetorical devices which make the language style of the novel unique and impressive.

In The Picture of Dorian Gray, rhetorical devices are widely used to add humor and vividness to the language of the novel. Metaphor, simile, personification, symbol, exaggeration and parallelism can be found here and there throughout the novel. With the help of these techniques, Wilde treats the material with such subtlety of observation, depth of psychological penetration and delicacy of touch that the novel becomes more vivid, effective and persuasive. Establishing a relationship at once and leaving more to the imagination, metaphor is a shortcut to meaning by setting two unlike things side by side to reveal the likeness between them. As metaphor compares one thing to another, the aesthetic effect of the language is thus enhanced.

A large number of metaphors are utilized in The Picture of Dorian Gray to enhance the vitality of the story. At the beginning of the novel, Lord Henry Wotton is so attracted by the handsome appearance of Dorian that he decides to allure him to follow his hedonistic theory, "Mr. Gray, you yourself, with your rose-red youth and your rose-white boyhood, you have had passions that have made you afraid, thoughts that have fined you with terror, day-dreams and sleeping dreams whose mere memory might stain your cheek with shame" (Wilde, 1994, p19). Here youth is compared to a red rose to show that it is fresh but transient. Meanwhile, boyhood is compared to a white rose to suggest its purity. Lord Henry also hints that in such a golden age Dorian might have passions and desires which make him afraid and give him terror because of the confine of the conventional ethics and morality. If Dorian restricts those adolescent impulsions, he might lose his beautiful youth completely without enjoying any pleasures. Such metaphors as "rose - red youth" and "rose-white youth" help not only to make the language of the novel vivid, but also to illustrate Wilde's belief in hedonism.

One afternoon in the little library of Lord Henry's house in Mayfair, Dorian Gray talks about Sybil Vane to Lord Henry, "But Juliet! Harry, imagine a girl, hardly seventeen years of age, with a little, flowerlike face, a small Greek head with plaited coils of dark-brown hair, eyes that were violet wells of passion, lips that were like the petals of a rose"(Wilde, 1994, p46). The beauty of Sybil's eyes is compared to "violet wells of passion". According to the theory of psychology, the character of a person can be deciphered from his or her eyes. Apparently, Lord Henry suggests that Sybil is a pure and kind girl who will be passionate and loyal to her lover eternally. With the help of those metaphors, Wilde makes his language capable of expressing maximum meaning with a minimum of words.

Apart from metaphors, similes are widely used in The Picture of Dorian Gray to help achieve the aesthetic effect of the language style. In a little private room at the Bristol, Dorian Gray, Lord Henry and Basil Hallward are having a dinner. Dorian tells them about Sybil's reaction after he kisses her for the first time. "She trembled all over and shook 
like a white narcissus. Then she flung herself on her knees and kissed my hands. I feel that I should not tell you all this, but I can't help it" (Wilde, 1994). In Greek myth, Narcissus is extremely beautiful. Here Dorian compares Sybil to "a white narcissus", not only to show that Sybil is a very beautiful girl, but also to imply that the girl is very pure. However, when Sybil performed not very well on the stage, Dorian discarded her ruthlessly. She begged for his forgiveness with a piteous expression of pain in her face and put her hand upon his arm. But she was refused. Then "A low moan broke from her, and she flung herself at his feet and lay there like a trampled flower" (Wilde, 1994, p77). "A trampled flower" is adopted to give a hint on Sybil's tragic ending. Here when "a white narcissus" is linked with "a trample flower", the underlying connection between each chapter can be perceived. As they are both used to describe Sybil Vane, the comparison between a delicate, charming narcissus and a rejected and trample flower on the ground is so distinct that Dorian's cruelty can be read. Hereby, the fact of Dorian's loving her performance (art) better than her herself can be seen between the lines.

At the outset of the novel, having heard the tempting words about the hedonistic lifestyle from Lord Henry, Dorian expresses his appreciation of Lord Henry. "There was something in his (Lord Henry's) low languid voice that was absolutely fascinating. His cool, white, flowerlike hands, even, had a curious charm. They moved, as he spoke, like music, and seemed to have a language of their own" (Wilde, 1994). Here by comparing Henry's hands to flower, and the moving hands to music, Dorian displays his consent to what Lord Henry's preaches. Through depicting Henry's charming hands, Wilde wants to convey to us that Dorian is completely attracted by the aesthetes that Lord Henry represents.

Like metaphors and similes, personifications are also the indispensable ingredients to add vividness and profundity to the language of the novel. With the utilization of personifications, something non-human can be attributed of a personal nature. The personifications in The Picture of Dorian Gray make the characters stand out in a strong and unforgettable position.

Lord Henry once exhibits his eloquent talent by making a speech at a party of the upper class. "The praise of folly...soared into a philosophy, and philosophy herself became young, and catching the mad music of pleasure, wearing, one might fancy, her wine-stained robe and wreath of ivy, danced like a Bacchant over the hills of life. ..." (Wilde, 1994). Here from the lexical angle, both "folly" and "philosophy" belong to neutral nouns describing abstract things. However, the praise of "folly" has become a philosophy. Here "philosophy" is personified as a fairy wears wreath of ivy, dances like a Bacchant and drinks wine. In addition, words as, soar, catch, mad, dance, mock, etc, give us such an immediate deep impression that it presents a fantastic world before us through the use of personification.

Lord Henry once lured Dorian by telling him time and again that the youth is transient. "Time is jealous of you, and wars against your lilies and your roses. You will become sallow, and hollow-cheeked, and dull-eyed. You will suffer horribly" (Wilde, 1994). Here time is personified into a person who wants to have a war against Dorian's youth and beauty. Though Dorian has attained the beauty by selling his soul to the devil, he hasn't reached the integration of the body and the soul. Therefore, he cannot defeat time, and he is doomed to unfortunate. The examples above prove that personifications are used smartly to help make the language elegant and refined, and they also contribute to express the author's belief in the integration of the body and the soul.

The rhetorical devices are deliberately arranged to add mystical and aesthetic colour to the novel, to make the language appear more effective and persuasive, and to make the story more connotative. In a word, the rhetorical devices are wittily used to help achieve the impressive aesthetic effect of the language, and at the same time, to help reveal Wilde's hearty pursuit of the beauty of his writing style.

\section{The Harmony of Wilde's Diction}

Apart from the witty rhetorical devices, harmonious diction is another important feature that helps to build up the uniqueness of Wilde's writing style. In The Picture of Dorian Gray, Wilde depicts the environment as if it really exists around us and portrays his characters as if he knows them well. Their virtues and vices are issued from their lips as naturally as the facile flow of their conversation.

As "the lord of language", Wilde lays much stress on the diction of the setting of the novel. At the very beginning of the story, "The studio was filled with the rich odour of roses, and when the light summer wind stirred amidst the trees of the garden, there came through the open door the heavy scent of the lilac, or the more delicate perfume of the pink-flowering thorn" (Wilde, 1994). Wilde employs the entire first paragraph to describe the picturesque natural environment out of the painting room, by using the phrases like "the rich odour of roses", "the light summer wind", "the heavy scent of the lilac" and "delicate perfume of the pink-flowering thorn" to build a relaxed and beautiful atmosphere for the three characters to appear on the stage. Surrounded by the perfume of flowers and staying in "the 
light summer wind" (Wilde, 1994, p5), people might feel relaxed and comfortable. However, a tragedy is about to take place. On the one hand, it reveals the brilliant literary talent of Oscar Wilde; and on the other, it shows Wilde's intense aesthetic sentiment about nature and life, which he also confesses in The Critic as Artist "For the artist is not concerned primarily with any theory of life but with life itself, with the joy and loveliness that should come daily on eye and ear from a beautiful external world (Holland, 1994).

According to Wilde, art is pure and perfect, and beauty is holy and away from the sordid reality. As the symbol of beauty, the garden is also described quite aesthetic with beautiful scenery. In Chapter One of the novel, the garden is described as follows, "And the two young men went out into the garden together and ensconced themselves on a long bamboo seat that stood in the shade of a tall laurel bush. The sunlight slipped over the polished leaves. In the grass, white daisies were tremulous" (Wilde, 1994). Here the two mentioned are respectively Lord Henry Wotton and Basil Hallward. Basil is asked to tell the secret about the portrait. Wilde provides them a setting with "a long bamboo seat that stood in the shade of a tall laurel bush", "the sunlight slipped over the polished leaves" and "in the grass, white daisies were tremulous" (Wilde, 1994, p 8). With such a picturesque environment, Wilde tries every possible means to construct an aesthetic background to serve as a foil to help the plot unfold.

As "the lord of the language", Wilde emphasizes more on the form, and believes that "Form, which is the birth of passion, is also the death of pain. And so, to return to the sphere of Art, it is form that creates not merely the critical temperament, but also the aesthetic instinct, that unerring instinct that reveals to one all things under their condition of beauty" (Holland, 1994) . In The Picture of Dorian Gray, Wilde displays his talent by stressing on the form of language and utilizes chains of beautiful words to construct an aesthetic world for the plots to evolve. For instance, a peaceful and tranquil dawn is depicted to enhance the evilness and cruelty of Dorian. "The darkness lifted, and flushed with faint fires, the sky hollowed itself into a perfect pearl. Huge carts filled with nodding lilies rumbled slowly down the polished empty street. The air was heavy with the perfume of the flowers" (Wilde, 1994). Compared with "a perfect pearl", "nodding lily" and "the perfume of the flowers", Dorian's heart is heavy because he discards Sybil ruthlessly just now. Contrasted with the beauty of "pearl" and "lily", Dorian's behavior to Sybil seems more ugly and cruel. Although the natural surrounding is peaceful and harmonious with perfume of flowers, the protagonist's inner world is not tranquil. Owing to this, Dorian's love has been given to an abstract beauty in a visional world rather than to a living girl in reality. With vivid depiction of the environment, Wilde compares Dorian's evil inner world to dim gas-lamps as well as narrow and gloomy streets. "The moon hung low in the sky like a yellow skull. From time to time a huge misshapen cloud stretched a long arm across and hid it. The gas-lamps grew fewer, and the streets more narrow and gloomy" (Wilde, 1994). By such depiction, Wilde presents us such a picture: in a narrow and dark street and in the dim light of the gas-lamps comes a handsome young man, who wants to experience the physical pleasure disregarding the confines of moral or ethics. Contrast to the shining of "the sun," the night is gloomy with the gas-lamps growing fewer. The street, where Dorian debauches himself, has many prostitutes and opium houses. Serving as a foil to his degenerating behavior, the street is also depicted as "gray" and "gloomy". Apparently Wilde compares "the moon" to "a yellow skull", which not only implies the darkness at the bottom of Dorian's heart but also embodies the implication of Dorian's degenerating behavior.

Apart from the effective environmental description, the harmony of diction also lies in the character portraying of the novel. It is evident that the changing of Dorian Gray's appearance constructs the main thread of the novel. Although Wilde only uses several phrases to describe it, the effect of his diction is very strong. "He was certainly wonderfully handsome, with his finely curved scarlet lips, his frank blue eyes, his crisp gold hair...All the candour of youth was there, as well as all youth's passionate purity" (Wilde, 1994, p17).Here Dorian Gray, an extremely handsome young man, is presented before us. And in Lord Henry's eyes, Dorian has "finely curved scarlet lips", "frank blue eyes", "crisp gold hair" and "passionate purity" (Wilde, 1994, p17). This laconic diction on the appearance of Dorian reflects the author's talent as the "lord of language" and makes it possible to allow the main plot to develop smoothly.

In the preface to 'The Picture of Dorian Gray' Wilde puts forward that 'those who find beautiful meanings in beautiful things are the cultivated. For these there is hope. They are the elect to whom beautiful things mean only beauty" (Wilde, 2014). The elegant character-portrayal of the novel shows Wilde's more emphasis on the form than the content; meanwhile, it suggests Wilde's worship of beauty as well, and "there is nothing sane about the worship of beauty. It is too splendid to be sane. Those of whose lives it forms the dominant note will always seem to the world to be pure visionaries" (qtd. in Holland, 1994). For example, the exquisite choice of words for Sybil Vane's beauty reveals Wilde's appreciation of beauty. "But Juliet! Harry, imagine a girl, hardly seventeen years of age, with a little, flowerlike face, a small Greek head with plaited coils of dark-brown hair, eyes that were violet wells of passion, lips that were like the petal of a rose. She was the loveliest thing I had ever seen in my life. You said to me 
once that pathos left you unmoved, but that beauty, mere beauty, could fill your eyes with tears "(Wilde, 1994).

Through the mouth of Dorian, Wilde vividly presents the beauty of Sybil to readers with such phrases as "flowerlike face", "dark-brown hair", "violet wells of passion" and "the petal of a rose", a girl of seventeen years old is really like a bud of a flower. Because of this, the death of a young and pretty girl like a flower may arouse our pity just as the withering of a beautiful flower does. The choice of diction reflects Wilde's appreciation of a beauty, thus to reveal his sincere pursuit of beauty in life.

Wilde also shows his talent in character portraying by depicting people in the downtrodden world. When depicting the workingmen, Wilde employs proper rhetoric techniques and appropriate expressions to show his respect to them. Let's take his description of James Vane-- Sybil Vane's brother for example. "The door opened and a young lad with rough brown hair came into the room. He was thick-set of figure, and his hands and feet were large and somewhat clumsy in movement" (Wilde, 1994, p56). Wilde chooses "rough", "thick-set", "large" and "clumsy" to introduce the behavior of James Vane clearly. Unlike his sister, James Vane is rough and full of hostility to Dorian Gray. Although Wilde doesn't talk too much about James Vane in the novel, he takes a positive attitude towards this character and tries to depict him as a representative of the people living in the underworld, who look "clumsy in movement" and not well-bred but honesty and passionate to their family. "James Vane, his half-sullen but wholly faithful care for his sister's honour, is as good as perhaps anything of the kind, marked by a homely but real pathos, sufficiently proving a versatility in the writer's talent, which should make his books popular"'(Beckson, 1970). Wilde as a versatile writer, is good at portraying those handsome and well-educated people in the upper class, and meanwhile, he also shows his talents in describing the plain-looking and ill-educated workingmen.

In a word, Wilde's talent in the diction lies both in his description of the picturesque environment and in his vivid portraying of characters. In The Picture of Dorian Gray, Wilde treats the environment as it really exists and portrays his characters with harmonious and careful diction as if he knows them well. Besides, the diction of the novel is laconic and elegant to express either poetic beauty in common sense or morbid beauty in a mystical and marvelous setting.

\section{The Beauty of Wilde's Language}

Winston Churchill was once asked whom he would like to meet and talk with in after life, and he replied without hesitation, "Oscar Wilde". This story reflects Wilde's outstanding ability in the dialogues. As the "lord of language", Wilde does a marvelous job in both public speech and literary writing with his eloquence and humor. To achieve the aesthetic effect of The Picture of Dorian Gray, he focuses on the gracefulness of the language with jocular dialogues. "He was the first to recognize his title. Words to him were the material of his art. If by their means he built with beauty and sincerity, his artistic conscience--the only conscience he would admit—was satisfied" (Winwar,1940,p 170). Besides, the terseness of phrases, the smartness of the repartees, the wittiness of epigrams and paradoxes all contribute to the form of the language in achieving the aesthetic effect. Therefore, as we turn to the language style of the novel, it is necessary for us to do some research into its language, especially those brilliant paradoxes, jocular dialogues and witty epigrams.

Brilliant paradoxes are Wilde's favorite rhetorical devices to make his language vivid and impressive. Paradoxes are typical of Wilde's language, which help him expose the inner world of the characters, and reveal his own aesthetic pursuit of beauty as well. "Oscar Wilde himself would explain the final paradox of the pose of Aesthetic dandy, he chooses, as all great dandies must, to put only his talent into his work, but his genius into his life" (Raby, 1997).Employing paradoxes, those statements, which seem to mean something opposite to the common sense, may contain a truth. In the novel, Lord Henry Wotton is such a master of language that his dialogues are full of paradoxes, through which Wilde manifests his ability to make the remarks humorous, and at the same time, displays his attack to morality and social ethos in that Victorian society. Besides that, they are employed as weapon to stab the hypocritical society as well. According to Bashford, it is "with a sudden flash of wit that Wilde exposes to our startled eyes the sheer cliff-like walls of the rift which has opened out, as if by a silent earthquake, between our moral belief and the belief of our fathers. That fissure is the intellectual revolution" (Bashford, 1999). In this respect, as the spokesman of Aestheticism, Wilde starts an intellectual revolution to display his attack on the conventions with the disguise of humorous paradoxes, witty dialogues and brilliant epigrams.

In The Picture of Dorian Gray, as a cynical aristocrat, Lord Henry likes to use paradoxes as a weapon to mock the evils of society, just like Wilde himself. Here are some paradoxes of Lord Henry Wotton. As a well-educated acrobat, Lord Henry has a very conventional marriage and feels content with his love of his wife. However, in his paradoxes, he puts forward that "Those who are faithful know only the trivial side of love, it is the faithless who know love's tragedies" (Wilde, 1994); "What a fuss people make about fidelity!"(Wilde, 1994); "Why, even in love it is purely a 
question for physiology. It has nothing to do with our own will. Young men want to be faithful, and are not; old men want to be faithless, and cannot, that is all one can say" (Wilde, 1994). Although Lord Henry Wotton is faithful to his wife, yet in his paradoxical speeches, he talks too much about the infidelity in love, and the hypocritical relationship between those who preach that they are loyal to each other forever. Seemingly Lord Henry Wotton is too cynical to believe faithful love. But actually it reveals his mock at the faithful lovers praised by the aristocracy and his deep thinking upon the so-called pure and devoted love of the aristocratic people. In Victorian Age, the acrobats preach that they are faithful to their lovers and the love between them is pure and holy. Nevertheless, their marriage is often connected with money and power. Cheating and betrayal of one's lover can frequently been seen among the upper class. Although they are contemplated by the nobles, people in the downtrodden class are often faithful to their lovers. Here Lord Henry's paradox actually reveals Wilde's opinions on love. Through Lord Henry's mouth, Wilde uses the paradoxical language to satirize the hypocritical relationship between lovers in the upper class. The alliterative words of "faithful, faithless and fidelity" not only help the paradox sound harmonious, but also add beauty to the language of the whole novel.

Wilde once admits that "I don't regret for a single moment having lived for pleasure... There was no pleasure I did not experience... Tired of being on the heights I deliberately went to the depths for new sensations" (Raby, 1997).To some extent, Lord Henry can be regarded as an incarnation of Wilde himself as a dandy. According to Wilde, Lord Henry is very eloquent, "He played with the idea and grew wilful; tossed it into the air and transformed it; let it escape and recaptured it; made it iridescent with fancy and winged it with paradox" (Wilde, 1994). As a "Prince Paradox" (Winwar, 1940), Lord Henry utilizes paradoxes to mock the hypocritical upper class in Victorian Age. He once talked about the relationship between the mediaeval art and the mediaeval emotion with Basil Hallward and Dorian Gray. He believes that the art is charming while the emotion is out of date. Based on that, he puts forward that "believe me, no civilized man ever regrets a pleasure, and no uncivilized man ever knows what a pleasure is" (Wilde, 1994). Seemingly, it suggests that those civilized men never regret to have a happy life while those uncivilized seldom know how to enjoy the pleasure of life. But actually Henry implies that those who can appreciate the beauty of the mediaeval art are the civilized ones while those who only have the mediaeval emotion are the uncivilized ones who don't know what a pleasure is.

Apart from paradoxes, jocular dialogues are also one of the most important features that add beauty to Wilde's language. The following dialogue between Lord Henry Wotton and Sir Thomas in the novel is listed.

"They say that when good Americans die they go to Paris," Chuckled Sir Thomas, who had a large wardrobe of Humor's cast-off clothes.

"Really! And where do bad Americans go to when they die?" inquired the duchess.

"They go to America," murmured Lord Henry (Wilde, 1994).

In the above dialogue, Sir Thomas praised the Americans and Lord Henry shows his disapproval of him. From the dialogue we can perceive that Wilde has quite a bad impression on America. As a typical aesthete, Wilde prefers France to America because Paris is the birthplace of Aestheticism. Owing to these, Wilde holds that Paris is the paradise for good Americans. When good people die, they will go to the paradise. What about bad men? Undoubtedly they will sink down into the hell. In a certain sense, Wilde wants to convey to readers his contemplation of America. Through the mouth of Lord Henry, Wilde reflects his prejudice against America in a humorous way.

Besides humor, the dialogues in the novel tend to be logical and meaningful. For example, about the relationship among the three main characters, Wilde arranges such a dialogue between Dorian Gray and Basil Hallward.

"Why, what did you expect, Dorian? You didn't see anything else in the picture, did you? There was nothing else to see?"

"No; there was nothing else to see. Why do you ask? But you mustn't talk about worship. It is foolish. You and I are friends, Basil, and we must always remain so."

"You have got Harry," said the painter sadly.

"Oh, Harry!" cried the lad, with a ripple of laughter.

"Harry spends his days in saying what is incredible and his evenings in doing what is improbable. Just the sort of life I would like to lead. But still I don't think I would go to Harry if I were in trouble. I would sooner go to you, Basil" (Wilde, 1994).

Through the dialogue, the delicate relationship among Dorian, Basil and Lord Henry can be perceived. At this moment, Dorian still possesses some of his consciousness. In addition, the ambiguous love between Basil and Dorian 
can be detected as well. Moreover, the implication of the dialogue is also vague. Although they are good friends, yet they don't want the other to know their own secret about the same picture. Lord Henry Wotton doesn't join in the dialogue. However, he still plays an important role in the talk because it is his tempting words that induce Dorian to make that demoniac oath. Jocular dialogues like this can be seen here and there in the novel and they are both interesting and meaningful.

The beauty of Wilde's language can also be seen in his use of epigrams to make his language vivid and humorous. At the outset of the novel, Dorian tells Lord Henry that he will be always glad to see Henry. However, Lord Henry answers, "Always! That is a dreadful word. It makes me shudder when I hear it. Women are so fond of using it. They spoil every romance by trying to make it last for ever. It is a meaningless word, too. The only difference between a caprice and a lifelong passion is that the caprice lasts a little longer" (Wilde, 1994). Here the last sentence is not only a paradox, but also an epigram. The caprice is generally disdained by people, while the lifelong passion is always highly praised. But Lord Henry employs this epigram to condemn the so-called eternal love preached by the upper class. By enumerating those women who change their lovers frequently, Lord Henry satirizes the hypocritical marital relationship in the upper class society.

As an aesthete, Lord Henry's opinion on the relationship between the soul and the senses is different from many others. At their first meeting, Lord Henry tells Dorian that "that is one of the great secrets of life-- to cure the soul by means of the senses, and the senses by means of the soul. You know more than you think you know, just as you know less than you want to know" (Wilde, 1994). It is because of the influence of this epigram that Dorian makes that demoniac oath. And it is because of the influence of this epigram that Dorian extremely seeks for physical pleasures beyond the restraint of the conventional morality. Apparently witty epigrams are typical of Wilde's language style, which add the vividness to the language and reinforce the appealing power of the novel.

Irony is the expression of one's meaning by saying something which is the direct opposite of one's thoughts, in order to make one's remarks forceful. As the "lord of language", Wilde is good at using ironies and puns to add to the beauty of his language. In the novel, through the mouth of the characters, Wilde displays his irony to the conventional morality and ethics of his age. In Chapter Four of the novel, when Dorian Gray describes how beautiful and lovely Sybil is, Lord Henry gives his opinions on women "as long as a woman can look ten years younger than her own daughter, she is perfectly satisfied. As for conversation, there are only five women in London worth talking to, and two of these can't be admitted into decent society" (Wilde, 1994). In Victorian Age, women were looked down upon by men even in the upper class. For men, they were decorations on public occasions or baby sitters at home. Here Lord Henry satirizes the upper class women who are either full of vanity or too ugly and vulgar. To him they are not even worth talking to in a conversation.

When Dorian Gray tells Lord Henry that the love between Sybil and himself is sacred, Lord Henry retorts that, "When one is in love, one always begins by deceiving one's self, and one always ends by deceiving others" (Wilde, 1994). This quotation can be regarded as a sharp irony to the lovers. Here Lord Henry challenges the conventional view on love. As love is holy, it is an eternal theme for literature, with which many famous authors have written a great number of novels, poems and plays. However, Lord Henry interrogates the holiness of love and holds that love is not only deceiving oneself, but also cheating others. Though it is quite cynical and radical, it exactly reflects Wilde's humorous reflection of the Victorian upper class society in which one's falling love with someone is only a thing that deceives oneself. If he fails, he will try to deceive someone else. Love cannot remain true and pure in that hypocritical society. With the irony, Wilde not only makes his language beautiful and harmonious, but also gives a bitter satire against the hypocritical aristocrats whose daily life is full of lies and deception.

\section{Conclusion}

Apparently, Wilde is at home with the clever use of witty rhetorical devices, harmonious diction and jocular dialogues. Witty rhetorical devices, harmonious diction and jocular dialogues are typical of Wilde's language style. Besides, witty epigrams, brilliant paradoxes, and sharp ironies not only add to the vividness of the novel, but also reinforce the beauty of the language.

As to the language style, Wilde's originality lies in his clever use of the English language as an instrument to add to the vividness, effectiveness and charming of the novel. The perfection of Wilde's language style lies in its flawless encapsulation of the insignificance in a word or phrase and the significant arrangement of these into an organic whole. But art is more than cleverness; it is a mode of perfection. Succinctness, vividness, impressiveness and meaningfulness form the most important features of Wilde's language.

Owing to the limitation of his own litery world, Wilde lays much more emphasis on the form than on the content of 
the novel. His attack on the deterioration of art and the utilitarian tendency of literature are sometimes disguised with too much wit and humour. However, we should not expect perfection in everything from a writer. Despite of its defects and flaws, The Picture of Dorian Gray still occupies a very important place in the English literature at the turn of the 20th century.

\section{Acknowledgements}

This work is supported by Top-notch Academic Programs Project of Jiangsu Higher Education Institutions (No. PPZY2015A012)

\section{References}

Bashford, Bruce. (1999). Oscar Wilde The Critic as Humanist. London: Associated University Presses.

Beckson, Karl. (1970). Oscar Wilde: The Critical Heritage. London: Routledge and KeganPaul.

Holland, Merlin. (1994). Complete Works of Oscar Wilde. London: Harper Collins Publisher.

Isobel, Murray. (1979). The Artist as Critic: Critical Writings of Oscar Wilde. Oxford: Oxford University Press.

Liu Bingshan. (1992). A Short History of English Literature. Zhengzhou: Henan People's Publishing House.

Raby, Peter. (1997). The Cambridge Companion to Oscar Wilde. London: Cambridge University Press.

Stuart Mason. (1914). A Bibliography of Oscar Wilde. London: T. Werner Laurie.

Walter Hamilton. (1986). The Aesthetic Movement in England. New York: Garland.

Wilde, Oscar. (2014). The Picture of Dorian Gray. Nanjing: Yilin Press, 2014.

Wilde, Oscar. (1994). Complete Works of Oscar Wilde. Glasgow: HarperCollins Publishers.

Winwar, Frances. (1940). Oscar Wilde and the Yellow'Nineties. New York: Harper \& Brothers Publishers. 